\title{
Chaetotaxy and setal diversity of grooming legs in species of porcelain crabs (Crustacea: Anomura: Porcellanidae)
}

\author{
Luciane Augusto de Azevedo Ferreira ${ }^{1,2}$ \& Marcos Tavares ${ }^{1,3}$ \\ 1 Universidade de São Paulo (USP), Museu de Zoologia (MZUSP). São Paulo, SP, Brasil. \\ 2 ORCID: 0000-0003-1683-9962. E-mail: lucianeaaf@gmail.com (corresponding author). \\ 3 ORCID: $\underline{0000-0002-7186-5787}$. E-mail: $\underline{\text { mdst@usp.br }}$
}

\begin{abstract}
The morphology of the fifth pereiopods was studied under scanning electron microscopy in ten species of porcelain crabs for chaetotaxy and setal diversity, namelly Megalobrachium pacificum, Megalobrachium roseum, Pachycheles grossimanus, Petrolisthes armatus, Petrolisthes tuberculatus, Pisidia brasiliensis, Pisidia longicornis, Polyonyx gibbesi, Porcellana platycheles and Porcellana sayana. Six setal types were identified: simple, pappose, sickle-shaped serrate, straight serrate, club-shaped and tooth-like cuspidate. Porcelain crabs can differ in the fifth pereiopod setal morphology, chaetotaxy and setal density, even among species within the same genus. The absence of sexual dimorphism of the grooming legs in porcelain crabs suggests that grooming eggs requires no particular grooming apparatus in females and that male and female are equal in grooming efficiency.
\end{abstract}

Key-Words. Fifth pereiopod; Porcellanid crabs; Seta; Setal types.

\section{INTRODUCTION}

Many decapod crustaceans use at least one pair of thoracopods for grooming the body. In anomuran crustaceans, the fifth pereiopod is chelate in males and females and differ significantly from other pereiopods by being distinctly morphologically reduced, markedly flexible, and often carried underneath the carapace. The fifth pereiopod is a cleaning appendage with cuticular outgrowths used to brush off fouling organisms and residues from gills, eggs and the general body surface (Bauer, 1977, 1981, 1989; Martin \& Abele, 1988; Forster \& Baeza, 2001). Grooming may also be effective in the removal of larvae and infective stages of rhizocephalan parasites of the branchial chamber in porcelain crabs (Ritchie \& Høeg, 1981).

It has been abundantly shown by others that sensory and respiratory structures as well as developing eggs may suffer severe fouling and agglomeration of residues from water when prevented from grooming (Bauer, 1977, 1981, 1989; Holmquist, 1989; Pohle, 1989; Keiler \& Richter, 2011). Different setal types are used for different mechanical functions (e.g., Schembri, 1982; Fleischer et al., 1992; Garm, 2004a, b), such as brushing, combing, and scraping. Thus, setal diversity enhances grooming and cleaning efficiency of the grooming structures.

The morphological diversity of setae and chaetotaxy (setal arrangement) on the groom- ing apparatus of the distal segments of the fifth pereiopod in the Anomura have been the focus of several studies, but less commonly so in the porcellanid crabs with ten species in five genera to date (Table 1). In this paper, we examine the chaetotaxy and setal diversity on the grooming apparatus of the fifth pereiopod in ten porcelain crabs species related to six genera.

Table 1. Porcelain crab species studied to date for grooming leg setation.

\begin{tabular}{ll}
\hline Megalobrachium pacificum & Present study \\
Megalobrachium roseum & Present study \\
Pachycheles grossimanus & Present study \\
Pachycheles monilifer & Fleischer et al., 1992 \\
Pachycheles rudis & Fleischer et al., 1992 \\
Petrolisthes armatus & Fleischer et al., 1992; Present study \\
Petrolisthes cabrilloi & Bauer, 1981; Fleischer et al., 1992 \\
Petrolisthes cinctipes & Fleischer et al., 1992 \\
Petrolisthes galathinus & Bauer, 1989 \\
Petrolisthes tuberculatus & Present study \\
Petrolisthes violaceus & Forster \& Baeza, 2001 \\
Pisidia bluteli & Keiler \& Richter, 2011 \\
Pisidia brasiliensis & Present study \\
Pisidia longicornis & Present study \\
Polyonyx gibbesi & Present study \\
Porcellana platycheles & Keiler \& Richter, 2011; Present study \\
Porcellana sayana & Present study \\
Raphidopus ciliatus & Keiler \& Richter, 2011 \\
\hline
\end{tabular}




\section{MATERIAL AND METHODS}

Several adult males and females from ten species of porcellanid crabs, in six genera, were obtained from the collections of the Museu de Zoologia, Universidade de São Paulo (MZUSP) and their fifth pereiopods (P5) were dissected using a stereomicroscope (Appendix 1). The specimens had been previously stored in $70 \%$ ethanol. The P5 were rinsed in a weak solution of dishwater detergent in distilled water prior to being cleaned mechanically by ultrasound ( $\sim 5$ minutes) and then by soft brushing while immersed in distilled water to remove excess fixative.

For scanning electron microscopy (SEM), entire P5 were dehydrated through a graded series of ethanol washes (25\%, 50\%, 75\%, 100\%) (Felgenhauer, 1987) and critical point dried using liquid $\mathrm{CO}_{2}$ (Bal Tec SCD-050). The P5 were mounted individually on aluminum stubs with double-sided conductive tape and studied through a LEO 440 scanning electron microscope.

The P5 setal terminology essentially follows that of Fleischer et al. (1992), Forster \& Baeza (2001) and Keiler \& Richter (2011). Abbreviations used include: P2-5, pereiopods 2 to 5 (pereiopod 5 is the grooming leg); St, station.

\section{RESULTS AND DISCUSSION}

\section{Comparative gross morphology of P5}

In porcelain crabs the 7-segmented $\mathrm{P} 5$ is much smaller and remarkably more slender and flexible than P2-P4 and truly chelate in males and females. There is no sexual dimorphism of the chelae. The coxa and basis is followed by an endopodite with five distinct segments: ischium, merus, carpus, propodus and dactylus (Figs. 1A; $2 \mathrm{~A} ; 3 \mathrm{~A}$; 4C; 5A, G; 6A, E; 7A, D).

The merus of the P5 is by far the longest segment in the leg. The carpus can be slightly shorter than merus, as in Pachycheles grossimanus, Petrolisthes armatus, P. tuberculatus, Pisidia longicornis and Porcellana platycheles (e.g., Figs. 4C, 5G), or distinctly shorter than merus in Megalobrachium pacificum, M. roseum, Pisidia brasiliensis, Polyonyx gibbesi and Porcellana sayana (e.g., Fig. 6A, E). However, while in Megalobrachium pacificum, M. roseum and Porcellana sayana, the fixed and the movable fingers leave a very distinct gap when the chela is closed (e.g., Figs. 2F; 7E), no such is the case in Pachycheles grossimanus, Petrolisthes armatus, Petrolisthes tuberculatus, Pisidia brasiliensis, P. longicornis, Polyonyx gibbesi and Porcellana platycheles, in which the fingers close completely without an apparent gap (e.g., Figs. 4F; 6B). Expectedly, true chelae pick and remove fouling and debris more easily than subchelae, and gaping chelae can fit closely and hold more firmly larger fouling objects and residues than non-gaping chelae. Bauer (1989) reported cheliped picking at the gills in Petrolisthes galathinus, and Fleischer et al. (1992) commented on the role played by chela in dealing with objects not removed by the grooming setae. Softness and thickness of the gill filaments in Petrolisthes spp. play a role in allowing insertion of the chela in between the narrowly spaced gill filaments (Høeg, 1985; Fleischer et al., 1992).

\section{Morphological adaptations of P5 to grooming}

The P5 coxa and basis are united by a very large arthrodial membrane (Figs. 1A; 4C; 5A, C), which allows for a tight fold of the leg against the coxa, lending great mobility to the grooming leg. The male gonopore (Fig. 6A) located on the coxa (see also Guinot et al., 2013: 14) is large, operculated, and without setae. The basis is very short and fused to ischium (Figs. 1A; $2 A ; 4 C ; 5 A, G ; 6 A$, E; $7 A, D$ ), with suture line visible (Fig. $3 E$ ), so that the basis-ischium form a functional unit lending extra strength to the leg movement. The ischium and merus are not fused together (Figs. 1A; 4C; 5G; 6E; 7A, D). The merus and carpus are disproportionately long, an adaptation to reach more distant parts of the body. The merus is excavated on its ventral surface so to allow for a tight fold of carpus (Fig. 6A, E). The merus and carpus are distinctly slender, dorsoventrally flattened and curved (Fig. 4C) so to fit the space between the carapace and the gills and match closely the surface curvature of the body underneath the carapace. The hinged articulation and the extensive area of arthrodial membrane between merus and carpus lend extra mobility to the grooming leg (Fig. 5G).

The flexibility of the pereiopods is enhanced by the fact that the movement of any two given contiguous segments is alternate and opposite to each other, so that if one given segment moves horizontally the next contiguous segment will move vertically so as to widen the moving range. The direction of the movement of a particular leg segment (whether horizontal or vertical) is given by the position of its particular condyles. Lateral to lateral articular condyles only permit dorsoventral movements, whereas dorsoventral articular condyles impose lateral to lateral movements. The pereiopod dactylus, for instance, articulates with the propodus through a pair of lateral to lateral articular condyles and, therefore, the dactylus can only execute vertical movements. The propodus articulates to carpus through a pair of dorsoventral articular condyles, which in turn articulates to merus through a pair of lateral to lateral articular condyles, and so forth. The articular condyles thus alternate from lateral to lateral to dorsoventral from dactylus to coxa, so that the leg segments move in respect to each other in an alternate fashion - vertical, horizontal, vertical, and so on. In P5, however, the articulation dactylus-propodus is rotated inward so that the articular condyles assume an almost dorsoventral position (instead of lateral to lateral as seen in P2 to P4; see Table 2) and, therefore, the chela is flipped onto its side, an adaptation for easy sliding into the constricted space between the carapace and the gills. Furthermore, whereas the thoracic somites I-VII are fused together and are immovable in relation to one another, in anomurans the last thoracic somite (VIII), which carries the $\mathrm{P} 5$, is not fused to the precedent somite (VII). The somite VIII is connected to somite VII through a large membranous area thus being movable and lending additional mobility to the grooming leg (Fig. 8A). 
Table 2. Position of the articular condyles between the leg segments, from dactylus to coxa in pereiopods 2 to 5 (P2 to P5). Note in P5 that the articulation propodus-dactylus is rotated so that the articular condyles assume a dorsoventral position. $\mathrm{D}=$ dactylus; $\mathrm{P}=$ propodus; $\mathrm{C}=$ carpus; $\mathrm{M}=$ merus; $\mathrm{Bi}=$ basis-ischium; $\mathrm{Cx}=$ coxa; $\mathrm{PI}-\mathrm{St}=$ thoracic pleura-thoracic sternum; $\mathrm{LI}=$ lateral to lateral; $\mathrm{Dv}=$ dorsoventral.

\begin{tabular}{ccccccc}
\hline Pereiopod segments & D/P & P/C & C/M & M/Bi & Bi/Cx & Cx/PI-St \\
\hline P2 to P4 & LI & Dv & LI & Dv & LI & Dv \\
\hline P5 & Dv & Dv & LI & Dv & LI & Dv \\
\hline
\end{tabular}

The grooming leg is furnished with a terminal, weak chela in which the movable dactylus is about $1 / 3$ to $1 / 4$ length of the propodus. The chela is very small being only $1 / 5$ to $1 / 7$ of the maximal length of the carpus; the fingers have a duckbill shape distally (Figs. 2E; 3F; $4 F ; 5 B, E ; 6 B, F-G ; 7 F)$. In resting position the grooming leg is folded in Z-form outside of the branchial chamber (Fig. 8B), but when extended inside the branchial chamber the terminal chela can reach far forward to the entire branchial region (Fig. 8C).

\section{Chaetotaxy and setal diversity on the grooming legs}

Generally, the dorsal surface of the P5 coxa and the subdistal end of basis-ischium have one small tuft of pappose setae each (Figs. 1A, C; 2B; 3D). The P5 merus has very scattered, minute pappose setae (Fig. 1D), while the distal parts of carpus, propodus and the entire dactylus are densely setose (Fig. 1A). Not surprisingly, the distal parts of carpus, propodus and dactylus also concentrate most of the setal diversity (Figs. 1A; 2E-F; 3F; 4F; 5C; 6B, F-G; $7 \mathrm{E}-\mathrm{F})$, since these are the parts of the grooming leg that most easily reach almost everywhere in the gill chamber and various areas of the body in general. Six distinct setal types were found in the P5 of the studied species: straight serrate setae, sickle-shaped serrate setae, pappose setae, simple setae, club-shaped setae, and tooth-like cuspidate setae. Setal distribution among species is summarized in Table 3 and chaetotaxy along the grooming leg is indicated in the Figs. $1 A ; 2 A ; 3 A ; 4 C ; 5 A, G ; 6 A, E ; 7 A, D$.

Club-shaped setae (CS), Figs. 1H; 2G; 3H; 4A, B, G; 5B, E, F; $6 C, D, G, H ; 7 G, H:$ Smooth, robust setae, terminal pore visible, tip discretely bifid. Cuticular ornamentations, such as denticles, setules or scales lacking (Fleischer et al., 1992; Forster \& Baeza, 2001). Multiple rows of these setae were found along the inner and outer margins of the chelae on both dactylus and propodus. The club-shaped setae were referred to as curved setae and small simple setae in Petrolisthes violaceus and Porcellana platycheles by Forster \& Baeza (2001) and Keiler \& Richter (2011), respectively.

Pappose setae (Pp), Figs. 1A, C, D; 2A, B; 3D; 4C; 6A, E; 7A: Shaft usually long, slender, without terminal pore. Setules long, randomly arranged along the entire length of shaft lending feather-like appearance to setae, as also seen in plumose setae (Fleischer et al., 1992; Forster \& Baeza, 2001;
Table 3. Chaetotaxy and setal diversity among the studied porcelain species. $C \mathrm{C}=$ coxa; $\mathrm{BI}=$ base-ischium; $\mathrm{M}=$ merus; $\mathrm{C}=$ carpus; $\mathrm{P}=$ propodus; $\mathrm{D}=$ dactylus; $P p t=$ tuft of pappose setae; $P p d=$ moderate dense fringe of pappose setae; $P$ ps = scarce and minute pappose setae; $\mathrm{SO}=$ simple setae; $\mathrm{S} 1=$ sickle-shaped serrate setae; $S S=$ straight serrate setae; $C S$ = club-shaped setae; $\mathrm{TC}=$ tooth-like cuspidate setae straight truncate, with no distinct terminal projections; $\mathrm{TC} s=$ tooth-like cuspidate setae truncate, with a strong, broadly curved, sharp, single mesial spine; $\mathrm{TCr}=$ tooth-like cuspidate setae rounded, with minute, slightly acuminate teeth, but no strong spine.

\begin{tabular}{|c|c|c|c|c|c|c|}
\hline Taxon & $C x$ & BI & M & C & $\mathbf{P}$ & D \\
\hline Megalobrachium pacificum & PptSO & Ppt & Ppd & SS & $\begin{array}{c}\text { SOS1 } \\
\text { SSCS } \\
\text { TCt }\end{array}$ & $\begin{array}{l}\text { SOSS } \\
\text { CSTCt }\end{array}$ \\
\hline Megalobrachium roseum & Ppt So & Ppt & Pps & SS & $\begin{array}{c}\text { SOS1 } \\
\text { SSCS } \\
\mathrm{TCr}\end{array}$ & $\begin{array}{l}\text { SOSS } \\
\text { CSTCr }\end{array}$ \\
\hline Pachycheles grossimanus & Ppt So & Ppt & Ppd & SS & $\begin{array}{c}\text { SOS1 } \\
\text { SSCS } \\
\text { TCt }\end{array}$ & $\begin{array}{l}\text { SOSS } \\
\text { CSTCt }\end{array}$ \\
\hline Petrolisthes armatus & Ppt So & Ppt & Ppd & SS & $\begin{array}{c}\text { SOS1 } \\
\text { SSCS } \\
\text { TCt }\end{array}$ & $\begin{array}{l}\text { SOSS } \\
\text { CSTCt }\end{array}$ \\
\hline Petrolisthes tuberculatus & Ppt So & Ppt & Pps & SS & $\begin{array}{c}\text { SOS1 } \\
\text { SSCS } \\
\text { TCS }\end{array}$ & $\begin{array}{l}\text { SOSS } \\
\text { CSTCS }\end{array}$ \\
\hline Pisidia brasiliensis & Ppt So & Ppt & Ppd & SS & $\begin{array}{c}\text { SOS1 } \\
\text { SSCS } \\
\text { TCt }\end{array}$ & $\begin{array}{l}\text { SOSS } \\
\text { CSTCt }\end{array}$ \\
\hline Pisidia longicornis & Ppt So & Ppt & Pps & SS & $\begin{array}{c}\text { SOS1 } \\
\text { SSCS } \\
\text { TCt }\end{array}$ & $\begin{array}{l}\text { SOSS } \\
\text { CSTCt }\end{array}$ \\
\hline Polyonyx gibbesi & Ppt So & Ppt & Ppd & SS & $\begin{array}{c}\text { SOS1 } \\
\text { SSCS } \\
\mathrm{TCr}\end{array}$ & $\begin{array}{l}\text { SOSS } \\
\text { CSTCr }\end{array}$ \\
\hline Porcellana platycheles & Ppt So & Ppt & Ppd & SS & $\begin{array}{c}\text { SOS1 } \\
\text { SSCS } \\
\text { TCt }\end{array}$ & $\begin{array}{l}\text { SOSS } \\
\text { CSTCt }\end{array}$ \\
\hline Porcellana sayana & Ppt So & Ppt & Ppd & SS & $\begin{array}{c}\text { SOS1 } \\
\text { SSCS } \\
\text { TCr }\end{array}$ & $\begin{array}{l}\text { SOSS } \\
\text { CSTCr }\end{array}$ \\
\hline
\end{tabular}

Garm, 2004b). In all the species studied the pappose setae were scattered arranged on the coxa and formed a dense tuft on the ventrodistal surface of ischium near the joint to the merus. These setae were also present as a fringe along the lateral margin of the merus. Fleischer et al. (1992) and Forster \& Baeza (2001: 608, fig. 1) recorded the presence of plumose setae in the ischium near the joint to the merus in both Petrolisthes cabrilloi and Petrolisthes violaceus, respectively. However, in P. cabrilloi and in P. violaceus the setules on the shaft are located randomly throughout the shaft, instead of arranged into two rows on the opposite sides of the shaft. For this reason, we interpret these setae to be pappose instead of plumose.

Simple setae (SO), Figs. 1A, B; 2E-G; 3A, E, F; 4A, F; 5B, E; $6 B, F, G ; 7 F$, G: Shaft slender, short or long, tapering distally, lacking cuticular ornamentations, such as denticles, setules or scales (Garm, 2004b; Keiler \& Richter, 2011). The simple setae were found sparsely on the coxa and surrounding the distal margin of the dactylus and propodus. The twisted tips of the simple setae (Fig. 5B) enable particles to adhere to the setae (Fleischer et al., 
1992). This setal type was referred to as smooth setae in Petrolisthes cabrilloi by Fleischer et al. (1992).

Sickle-shaped serrate setae (S1), Figs. 1A, G; 2A, E; 3A, F, G; $4 C, F ; 5 A, C, D ; 6 A, B, F ; 7 F$ : Shaft very long, curved, with double row of spaced denticles; distal edge (tip of seta) slender, twisted, devoid of denticles (Fleischer et al., 1992; Forster \& Baeza, 2001; Keiler \& Richter, 2011). This setal type was found on the ventral surface of propodus, with a larger portion present on the proximal margin, and a smaller portion on the distal margin. The sickle-shaped serrate setae are always in contact with the gills as a result to their position on the propodus (e.g., Fig. 4F). Fleischer et al. (1992) commented that sickle-shaped serrate setae can be used for scraping and their curved, serrated part can reach difficult-of-access body areas (e.g., between gill filaments) thus enhancing grooming efficiency. Fleischer et al. (1992: 428, fig. 3E) and Forster \& Baeza (2001: 608, fig. 1) referred to the sickle-shaped serrate setae in Petrolisthes cabrilloi and $P$. violaceus, respectively, as sickle-shaped setae.

Straight serrate setae (SS), Figs. 1A, E, F; 2A, C-F; 3A-C, F; 4C-F; 5A-C, E, G; 6A, B, E, F; 7A, E, F: Shaft with two double dense rows of denticles, which point forward along twothirds of the shaft's length distally (Fleischer et al., 1992; Forster \& Baeza, 2001; Keiler \& Richter, 2011). Straight serrate setae were present in large numbers on the ventral and dorsal surfaces of propodus and dactylus. The carpus bore a tuft of straight serrate setae ventrodistally. The strong denticulation of the straight serrate setae (Fig. 4E) are used for combing and grooming (Schembri 1982; Watling, 1989). This setal type was named as straight long setae in Petrolisthes violaceus and composite serrate setae in Pisidia bluteli by Forster \& Baeza (2001: 608, fig. 1) and Keiler \& Richter (2011: 349, fig. 2F), respectively.

Tooth-like cuspidate setae (TC), Figs. 1A, H; 2F-H; 3F, H; 4A, B, F-H; 5B, E, F, H; 6B-D, G, H; 7B, C, F-H: Robust, slightly curved tooth-shaped outgrowth along chela margins (Fig. 6C, G). Each seta is divided into an inner and an outer part with a terminal pore (Fig. $1 \mathrm{H} ; 6 \mathrm{D}$ ) (see also Fleischer et al., 1992). In the literature this seta has also been called "teeth setae" in Petrolisthes cabrilloi and "tooth-shaped projections" in P. violaceus by Fleischer et al. (1992: 428, fig. 3F) and Forster \& Baeza (2001: 608), respectively.

\section{Comparative chaetotaxy}

Porcelain crabs can differ in P5 setal morphology, chaetotaxy and setal density, even among species within the same genus. The tooth-like cuspidate setae around the chelae varies in morphology according to species. In Megalobrachium pacificum, Pachycheles grossimanus, Petrolisthes armatus, Pisidia brasiliensis, P. longicornis and Porcellana platycheles, the tooth-like cuspidate setae were straight truncate and provided with no distinct terminal projections (Figs. $1 \mathrm{H} ; 3 \mathrm{H} ; 4 \mathrm{~A}, \mathrm{~B}, \mathrm{G}, \mathrm{H} ; 5 \mathrm{H} ; 6 \mathrm{C}, \mathrm{D} ; 7 \mathrm{C}$ ), whereas in Petrolisthes tuberculatus the distal margin of the toothlike cuspidate setae was also truncate, but furnished with a strong, broadly curved, sharp, single mesial spine (Fig. 5F). Contrary, in Megalobrachium roseum, Polyonyx gibbesi and Porcellana sayana the distal margin of the tooth-like cuspidate setae was rounded, provided with minute, unevenly sized, slightly acuminate teeth, but never formed a strong spine as in Petrolisthes tuberculatus (Figs. $2 \mathrm{H} ; 6 \mathrm{H} ; 7 \mathrm{H}$ ).

Fleischer et al. (1992) found almost no interspecific differences in the morphology of P5 in Petrolisthes spp. and only little differences between Petrolisthes spp. and Pachycheles spp. However, Petrolisthes cinctipes and P. galathinus (from Fleischer et al., 1992: 4B-C, respectively) differ from the single-spined $P$. tuberculatus (Fig. 5F) in having a pair of terminal spines in the tooth-like cuspidate setae, whereas Petrolisthes cabrilloi has no terminal spines (Fleischer et al., 1992: 4D). Mediterranean Sea specimens of Porcellana platycheles were reported to have a pair of terminal spines in the tooth-like cuspidate setae (Keiler \& Richter, 2011: fig. 6F), while the southwestern Atlantic specimens studied herein are devoid of any terminal spines (Fig. 7C). Keiler \& Richter (2011) reported artificial abrasions in Porcellanidae spp. In the southwestern Atlantic specimens of $P$. platycheles tooth-like cuspidate setae are very similar in size and shape to one another, suggesting that their feature is not the result of abrasion. A moderate dense fringe of pappose setae were present on the lateral margin of merus in Megalobrachium pacificum, Pachycheles grossimanus, Petrolisthes armatus, Pisidia brasiliensis, Polyonyx gibbesi, Porcellana platycheles and $P$. sayana (Figs. 1A, D; 4C; 7A), whereas pappose setae are scarce and minute on the lateral margin of merus in Megalobrachium roseum, Petrolisthes tuberculatus and Pisidia longicornis (Fig. 5A, G).

In the Petrolisthes spp. and Pachycheles spp. studied by Fleischer et al. (1992), simple setae (termed smooth setae by Fleischer et al., 1992) were restricted to the chelae margins, whereas in Petrolisthes armatus and P. tuberculatus and Pachycheles grossimanus, but also in Megalobrachium roseum, M. pacificum, Pisidia brasiliensis, P. longicornis, Polyonyx gibbesi, Porcellana platycheles and $P$. sayana (present study), simple setae were found additionally in tufts on the P5 coxa (e.g., Fig. 1A, B) and scattered over the leg.

Fleischer et al. (1992) suggested that the porcellanid P5 ground pattern is fitted to deal with a variety of situations and removal of fouling and foreign objects and even the removal of parasites requires no particular adaptations. In addition, we submit that the absence of sexual dimorphism of the grooming legs in porcelain crabs suggests that grooming eggs requires no particular grooming apparatus in females and that male and female are equal in grooming efficiency.

\section{ACKNOWLEDGEMENTS}

We gratefully thank the two anonymous referees for their helpful comments. We also thank Lara Guimarães (MZUSP) for assistance with the SEM work. MT thanks CNPq/Protax (440426/2015-4) for financial support and post-doctoral fellowship to LAAF (CNPq 165957/2015-8). 

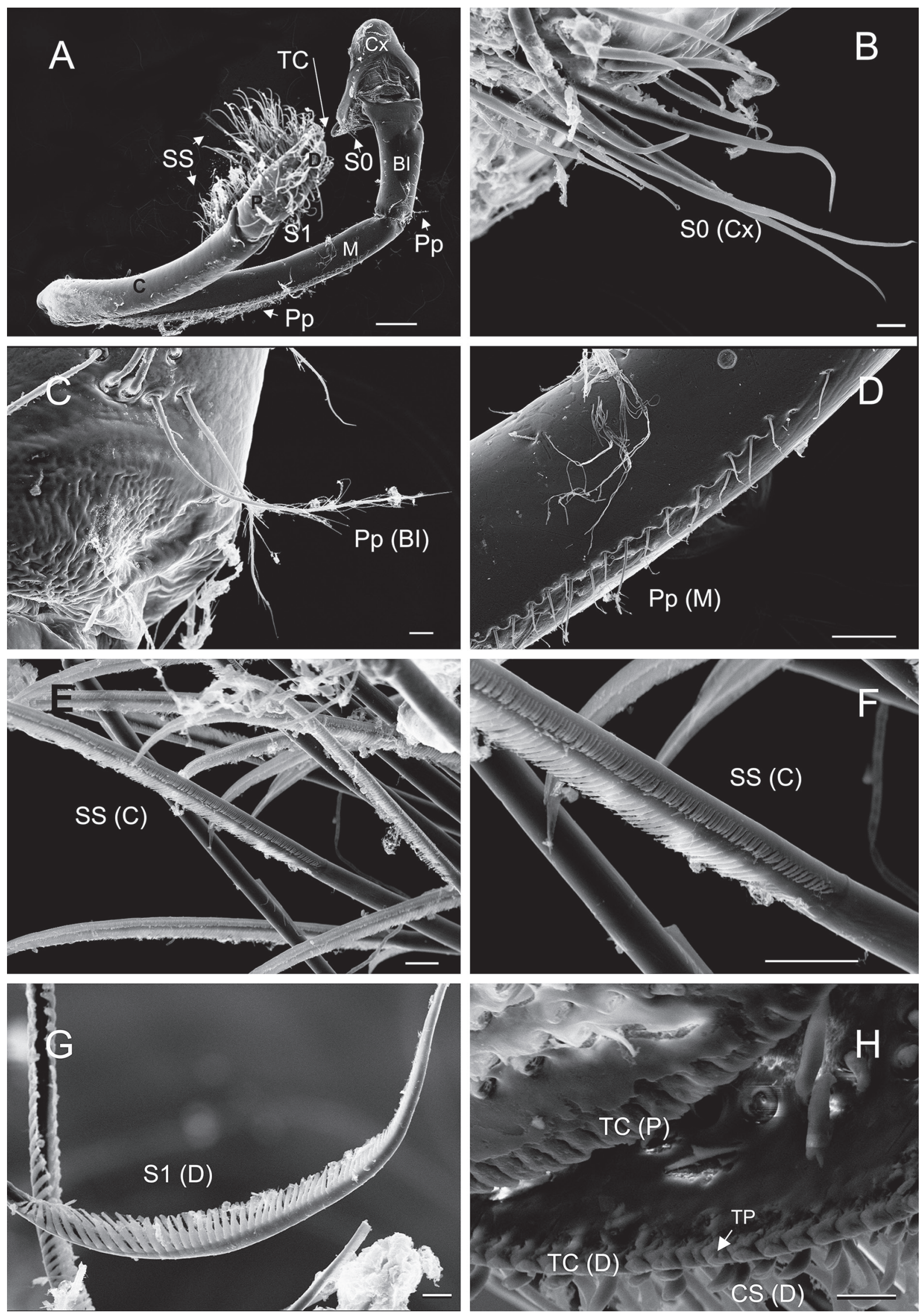

Figure 1. (A-H) Photomicrograph (SEM) of grooming leg, Megalobrachium pacificum Gore \& Abele, 1974, female (MZUSP 33040). (A) Left P5, ventral view. (B) Simple setae on distomesial surface of coxa. (C) Pappose setae on distolateral surface of basis-ischium. (D) Pappose setae on lateral surface of merus. (E) Straight serrate setae on distal surface of carpus, ventral view. (F) Detail of the straight serrate setae on distal surface of carpus. (G) Sickle-shaped serrate setae on distoventral surface of dactylus. $(\mathrm{H})$ Tooth-like cuspidate setae and club-shaped setae on distal margin of dactylus (chelae). $\mathrm{Cx}=$ coxa; $\mathrm{BI}=$ basis-ischium; $\mathrm{M}=$ merus; $\mathrm{C}=$ carpus; $\mathrm{P}=$ propodus; $\mathrm{D}=$ dactylus; $\mathrm{CS}=$ club-shaped setae; $\mathrm{Pp}=$ pappose setae; $\mathrm{SO}=$ simple setae; $\mathrm{S} 1$ = sickle-shaped serrate setae; $\mathrm{SS}=$ straight serrate setae; $\mathrm{TC}=$ tooth-like cuspidate setae; $T P=$ terminal pore. Scale bars = (A) $0.3 \mathrm{~mm} ;(B, C, E-H) 0.01 \mathrm{~mm}$; (D) $0.1 \mathrm{~mm}$. 

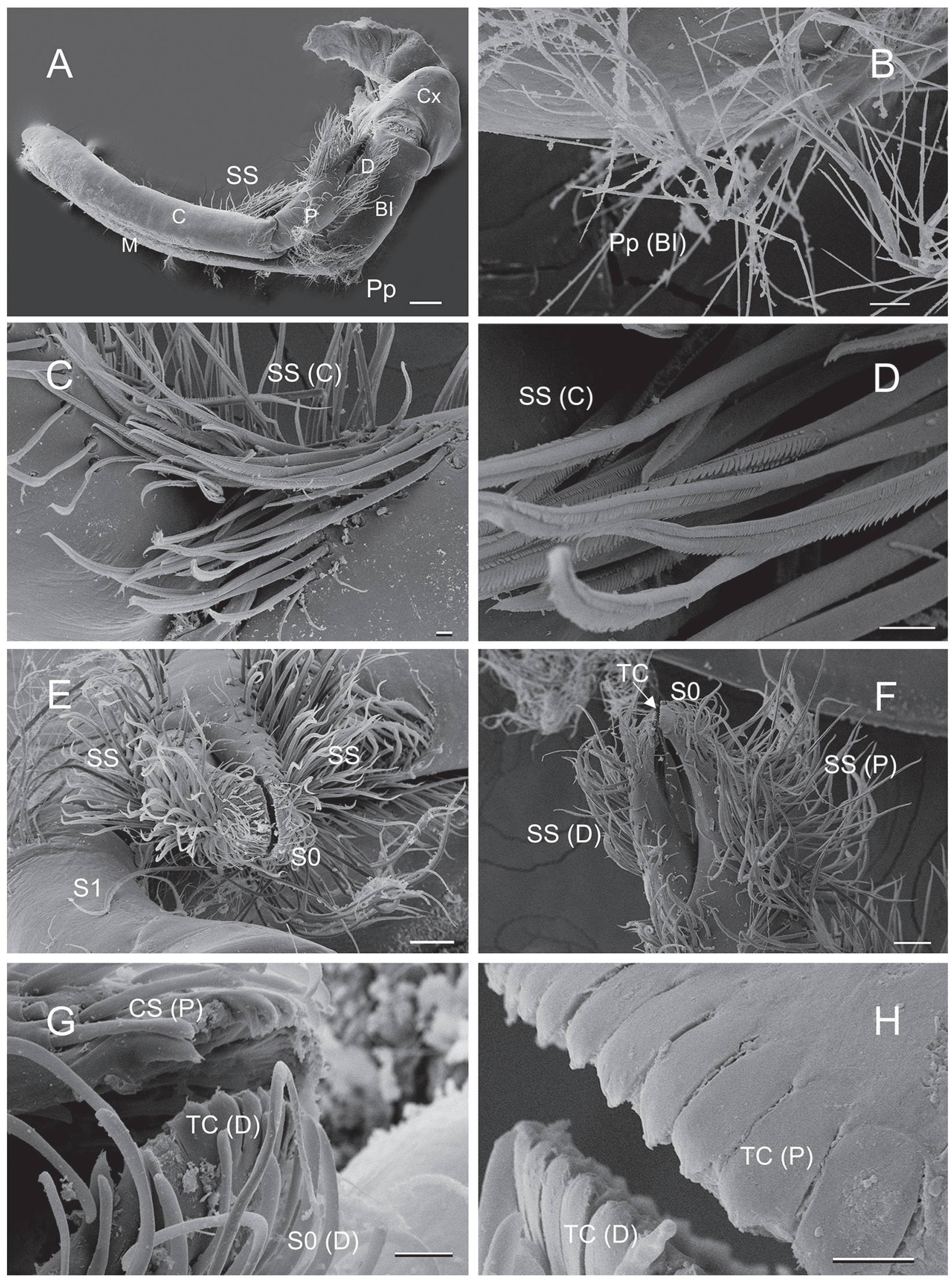

Figure 2. (A-H) Photomicrograph (SEM) of grooming leg, Megalobrachium roseum (Rathbun, 1900), female (MZUSP 33143). (A) Left P5, ventral view. (B) Pappose setae on distolateral surface of basis-ischium. (C) Straight serrate setae on distal surface of carpus, ventral view. (D) Detail of the straight serrate setae on distal surface of carpus. (E) Distal surface of chela (propodus and dactylus), frontal view. (F) Dactylus and distal third of propodus, lateral view. (G) Distal margin of propodus and dactylus with tooth-like cuspidate and club-shaped setae. (H) Detail of tooth-like cuspidate setae on distal margin of propodus and dactylus. Note in $\mathrm{F}$ distinct gap between fixed and movable fingers when chela is closed. $\mathrm{Cx}=$ coxa; $\mathrm{BI}=$ basis-ischium; $\mathrm{M}=$ merus; $\mathrm{C}=$ carpus; $\mathrm{P}=$ propodus; $\mathrm{D}=$ dactylus; $\mathrm{CS}=\mathrm{club}$-shaped setae; $\mathrm{Pp}=$ pappose setae; $\mathrm{S} 0$ = simple setae; $\mathrm{S} 1$ = sickle-shaped serrate setae; $\mathrm{SS}=$ straight serrate setae; $\mathrm{TC}=$ tooth-like cuspidate setae. $\mathrm{Scale}$ bars $=(\mathrm{A}) 0.1 \mathrm{~mm}$; (B-D, G) $0.01 \mathrm{~mm}$; (E, F) $0.05 \mathrm{~mm}$; (H) $0.005 \mathrm{~mm}$. 

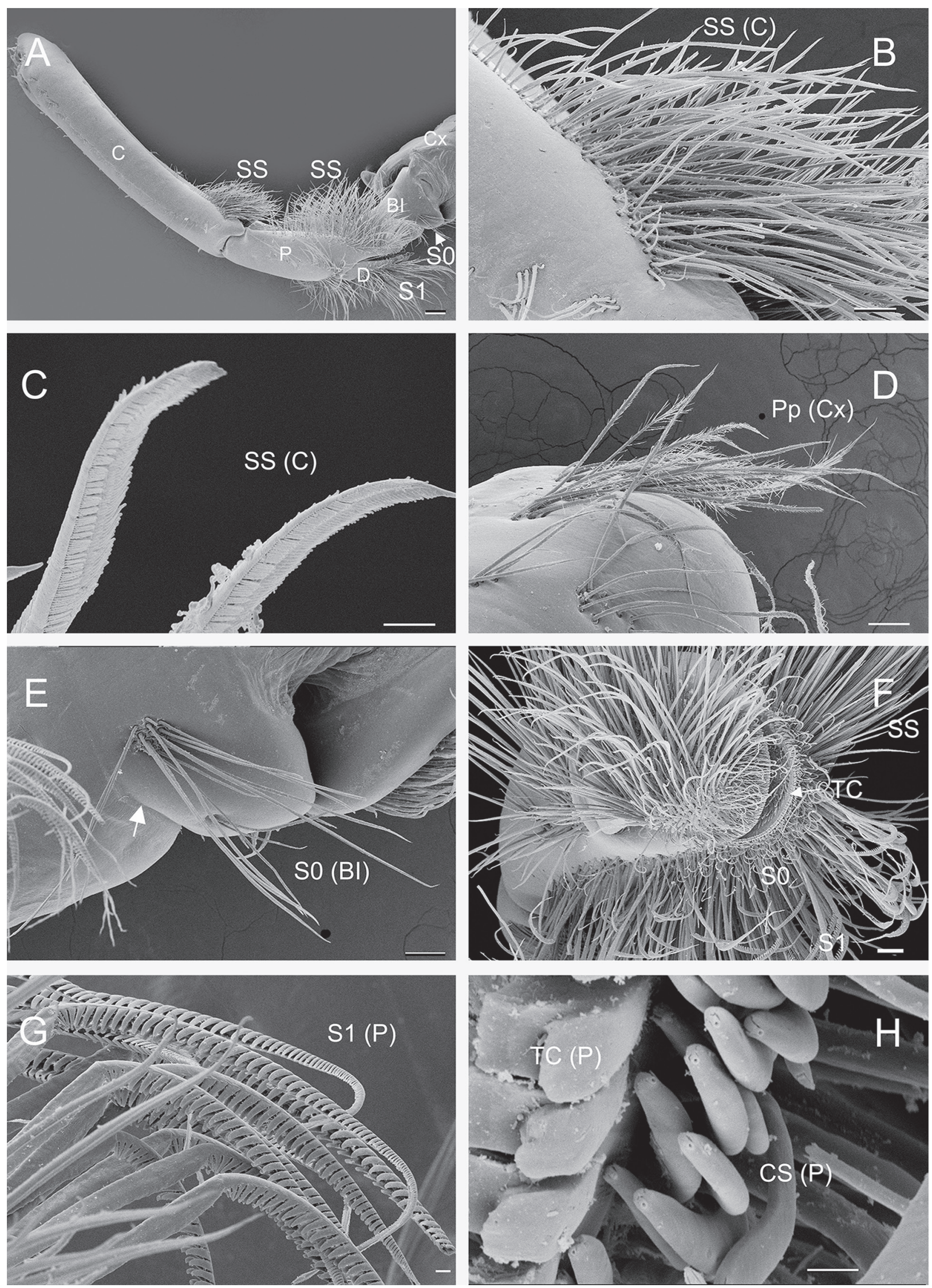

Figure 3. (A-H) Photomicrograph (SEM) of grooming leg, Pachycheles grossimanus (Guérin, 1835), male (MZUSP 26392). (A) Left P5, ventral view. (B) Straight serrate setae on distal surface of carpus, lateral view. (C) Detail of the straight serrate setae on distal surface of carpus. (D) Pappose setae (several setae with abraded setulae) on lateroproximal surface of coxa. (E) Simple setae on lateroproximal surface of basis-ischium (arrow indicates the suture line between the basis-ischium). (F) Distal surface of chela, frontal view. (G) Sickle-shaped serrate setae on distoventral surface of propodus. (H) Tooth-like cuspidate and club-shaped setae on distal margin of propodus. $\mathrm{C}=$ = coxa; $\mathrm{BI}=$ basis-ischium; $\mathrm{M}=$ merus; $\mathrm{C}=$ carpus; $\mathrm{P}=$ propodus; $\mathrm{D}=$ dactylus; $\mathrm{CS}=$ club-shaped setae; $\mathrm{Pp}=$ pappose setae; $\mathrm{SO}=$ simple setae; $\mathrm{S} 1=$ sickle-shaped serrate setae; $S S=$ straight serrate setae; $T C=$ tooth-like cuspidate setae. Scale bars = (A) $0.3 \mathrm{~mm} ;(B, D-F) 0.1 \mathrm{~mm} ;(C, G) 0.01 \mathrm{~mm} ;(H) 0.005 \mathrm{~mm}$. 

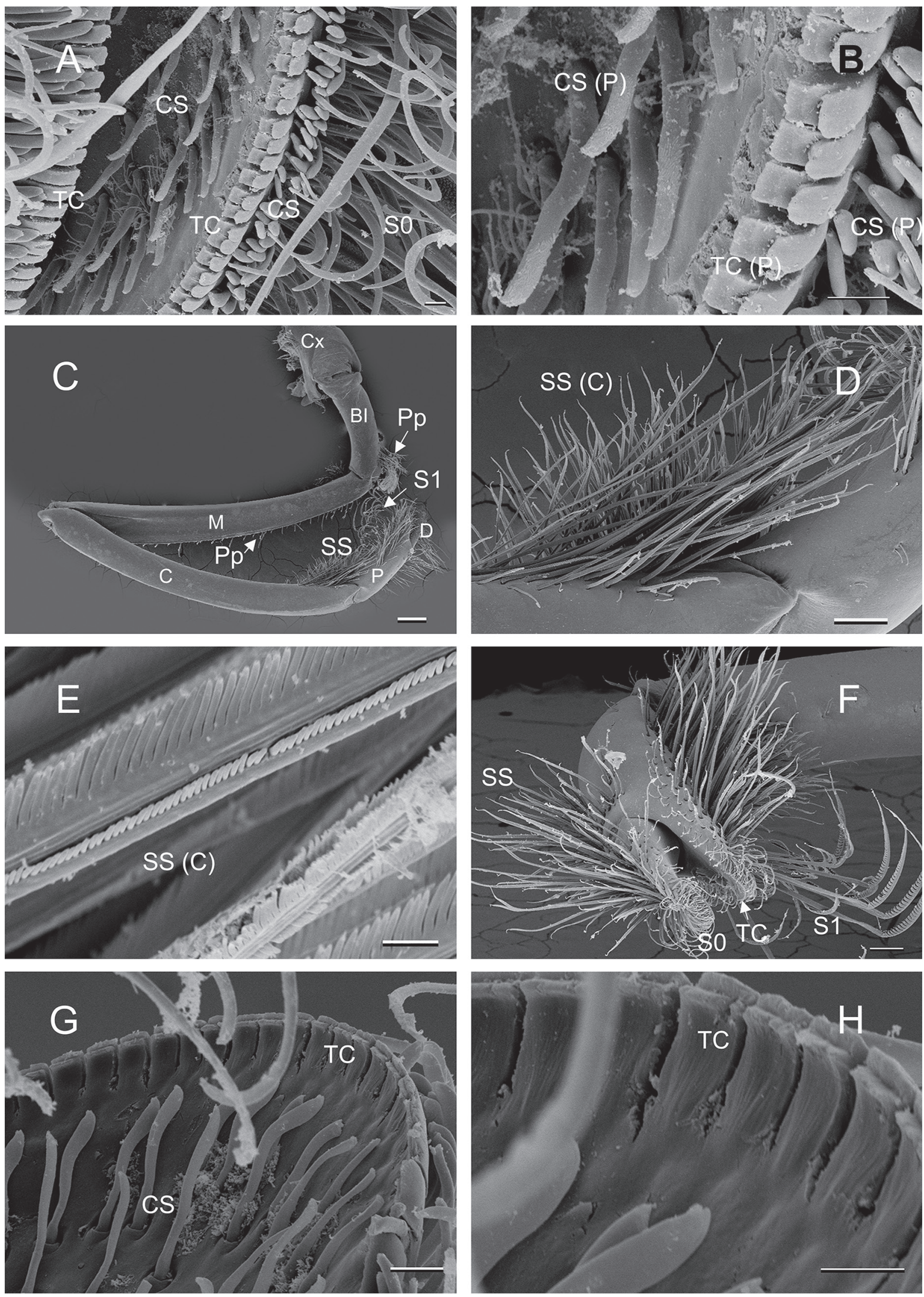

Figure 4. (A, B) Photomicrograph (SEM) of grooming leg, Pachycheles grossimanus (Guérin, 1835), male (MZUSP 26392). (A) Distal margin of propodus and dactylus, frontal view showing tooth-like cuspidate and club-shaped setae. (B) Detail of tooth-like cuspidate and club-shaped setae on distal margin of propodus. (C-H) Photomicrograph (SEM) of grooming leg, Petrolisthes armatus (Gibbes, 1850), male (MZUSP 24562). (C) Left P5, ventral view. (D) Straight serrate setae on distal surface of carpus. (E) Detail of the straight serrate setae on distal surface of carpus. (F) Dactylus and propodus, lateral view. (G) Tooth-like cuspidate and club-shaped setae on distal margin of dactylus. $(\mathrm{H})$ Detail of tooth-like cuspidate setae on distal margin of dactylus. $\mathrm{Cx}=$ coxa; $\mathrm{BI}=$ basis-ischium; $\mathrm{M}=$ merus; $\mathrm{C}=$ carpus; $\mathrm{P}=$ propodus; $\mathrm{D}=$ dactylus; $\mathrm{CS}$ = club-shaped setae; $\mathrm{Pp}=$ pappose setae; $\mathrm{SO}=$ simple setae; $\mathrm{S} 1$ = sickle-shaped serrate setae; $\mathrm{SS}=$ straight serrate setae; $\mathrm{TC}=$ toothlike cuspidate setae. Scale bars = (A, B, G) $0.01 \mathrm{~mm} ;(C) 0.3 \mathrm{~mm}$; (D, F) $0.1 \mathrm{~mm} ;(E, H) 0.005 \mathrm{~mm}$. 

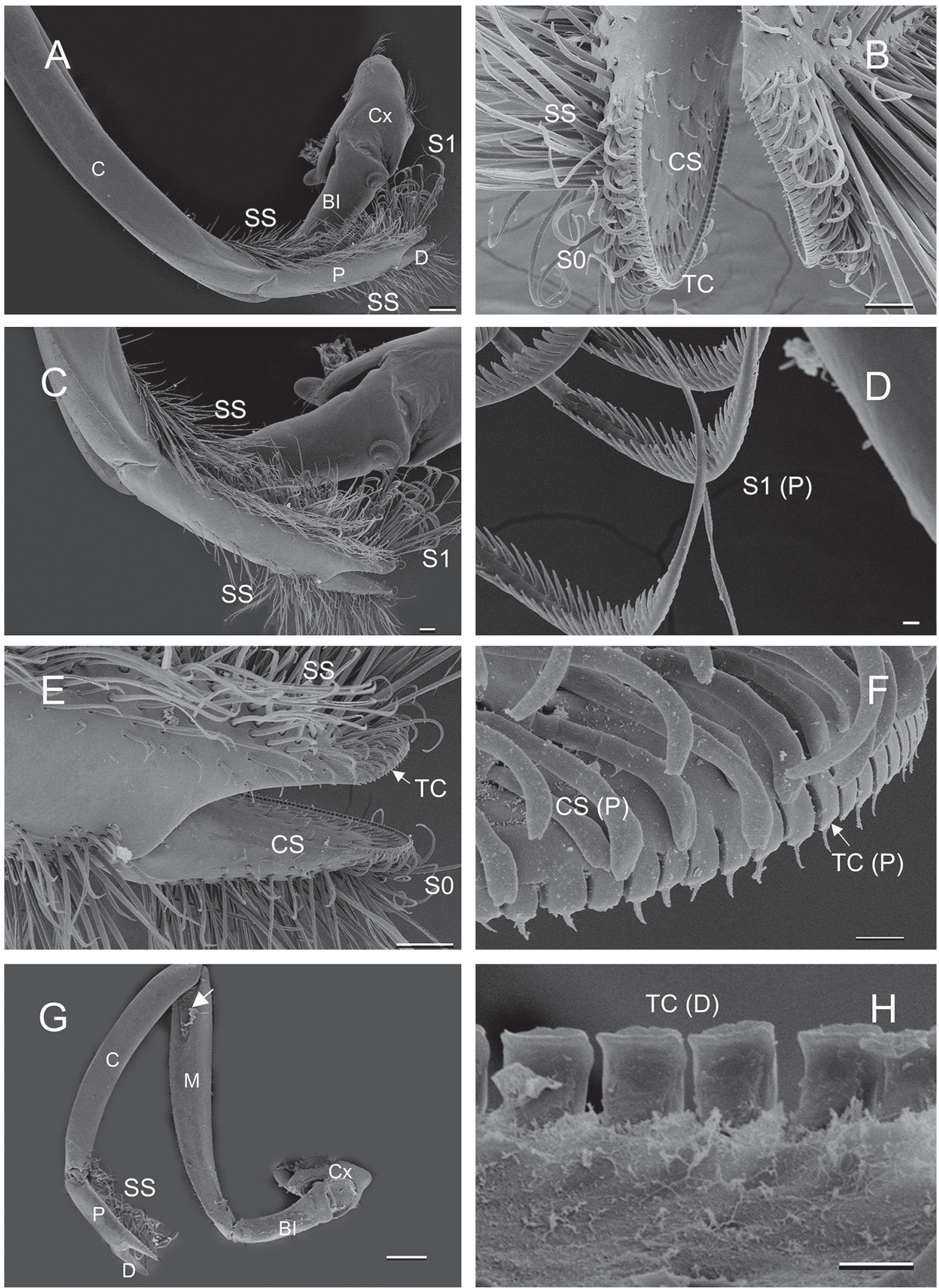

Figure 5. (A-F) Photomicrograph (SEM) of grooming leg, Petrolisthes tuberculatus (Guérin, 1835), male (MZUSP 25888). (A) Left P5, ventral view. (B) Distal surface of propodus and dactylus, lateral view. (C) Propodus and dactylus, lateral view. (D) Sickle-shaped serrate setae on distal surface of propodus. (E) Dactylus and distal third of propodus, lateral view. (F) Tooth-like cuspidate and club-shaped setae on distal margin of propodus. (G, H) Photomicrograph (SEM) of grooming leg, Pisidia longicornis (Linnaeus, 1767), male (MZUSP 18730). (G, H) Photomicrograph (SEM) of grooming leg, Pisidia longicornis (Linnaeus, 1767), male (MZUSP 18730). (G) Left P5, ventral view (arrow indicates the hinged articulation and the extensive area of arthrodial membrane between merus and carpus). (H) Tooth-like cuspidate setae on distal margin of dactylus. Note in $B$ scattered club-shaped setae on the closing surface of dactylus, and in $F$ tooth-like cuspidate setae furnished with a strong, single median spine. $\mathrm{CX}=$ coxa; $\mathrm{Bl}=$ basis-ischium; $\mathrm{M}=$ merus; $\mathrm{C}=$ carpus; $\mathrm{P}=$ propodus; $\mathrm{D}=$ dactylus; $\mathrm{CS}=$ club-shaped setae; $\mathrm{Pp}=$ pappose setae; $\mathrm{S} 0=$ simple setae; $\mathrm{S} 1=$ sickle-shaped serrate setae; $\mathrm{SS}=$ straight serrate setae; $\mathrm{TC}=$ tooth-like cuspidate setae. Scale bars $=(\mathrm{A}, \mathrm{G}) 0.3 \mathrm{~mm} ;(\mathrm{B}, \mathrm{H}) 0.005 \mathrm{~mm}$; (C, E) $0.1 \mathrm{~mm}$; (D, F) $0.01 \mathrm{~mm}$. 

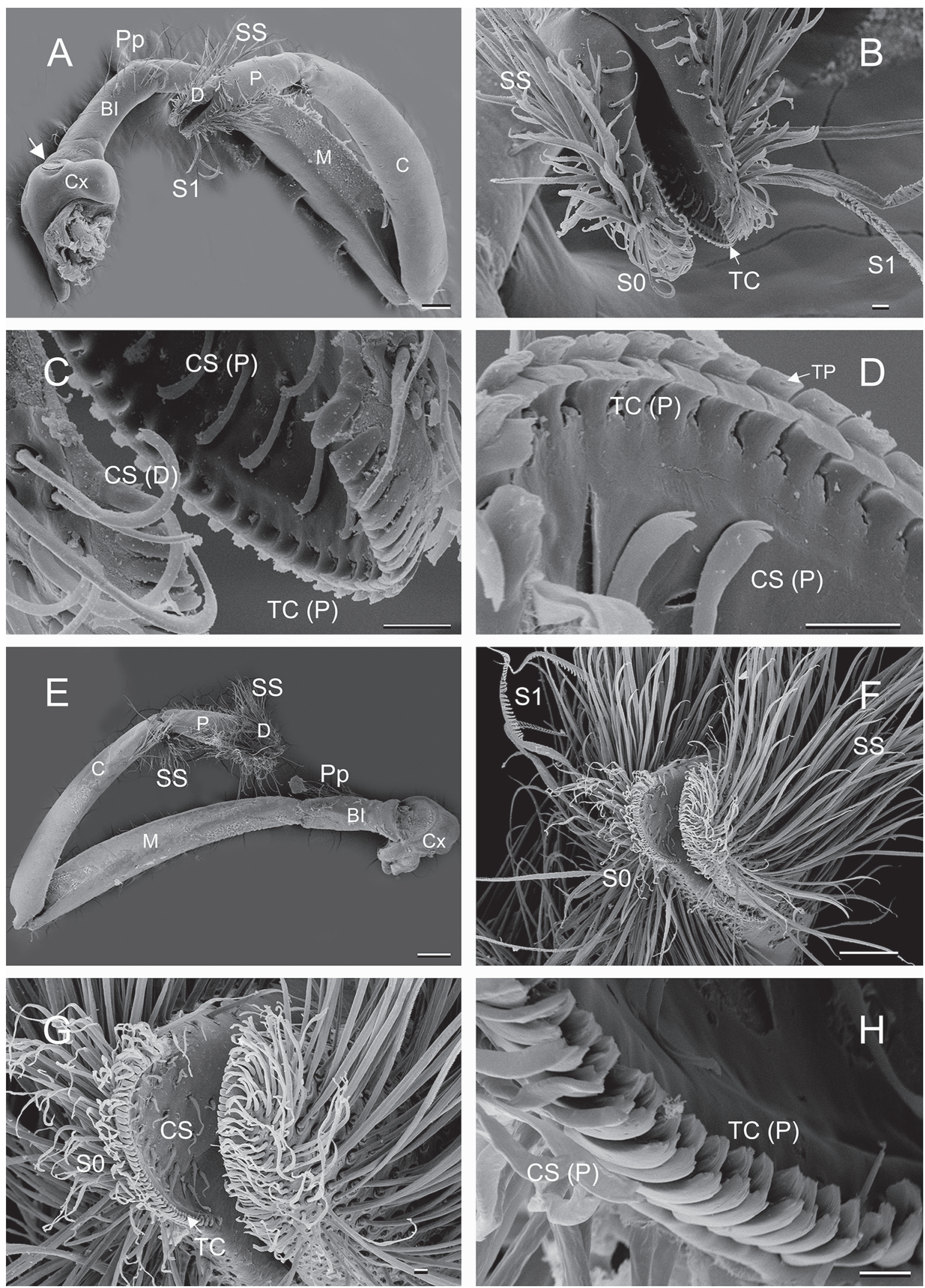

Figure 6. (A-D) Photomicrograph (SEM) of grooming leg, Pisidia brasiliensis Haig in Rodrigues da Costa, 1968, male (MZUSP 23355). (A) Right P5, ventral view (arrow indicates the male gonopore). (B) Dactylus and distal third of propodus, lateral view. (C) Distal margin of propodus and dactylus with tooth-like cuspidate, club-shaped and simple setae. (D) Tooth-like cuspidate and club-shaped setae on distal margin of propodus. Note in D the inner and outer parts of tooth and terminal pore. (E-H) Photomicrograph (SEM) of the grooming leg, Polyonyx gibbesi Haig, 1956, male (MZUSP 19524). (E) Left P5, ventral view. (F) Distal surface of propodus and dactylus, frontal view. (G) Detail of distal surface of propodus and dactylus, frontal view. (H) Tooth-like cuspidate setae and club-shaped setae on distal margin of propodus. Note in $\mathrm{H}$ the tooth-like cuspidate setae provided with minute, unevenly sized, slightly acuminate teeth. $\mathrm{Cx}=\operatorname{coxa} ; \mathrm{BI}=$ basis-ischium; $\mathrm{M}=$ merus; $\mathrm{C}=$ carpus; $P=$ propodus; $D=$ dactylus; $C S=$ club-shaped setae; $P p=$ pappose setae; $S 0=$ simple setae; $S 1=$ sickle-shaped serrate setae; $S S=$ straight serrate setae; $T C=$ tooth-like cuspidate setae; $T P=$ terminal pore. Scale bars $=(A, F) 0.1 \mathrm{~mm} ;(B, C, G) 0.01 \mathrm{~mm} ;(D, H) 0.005 \mathrm{~mm}$; (E) $0.3 \mathrm{~mm}$. 

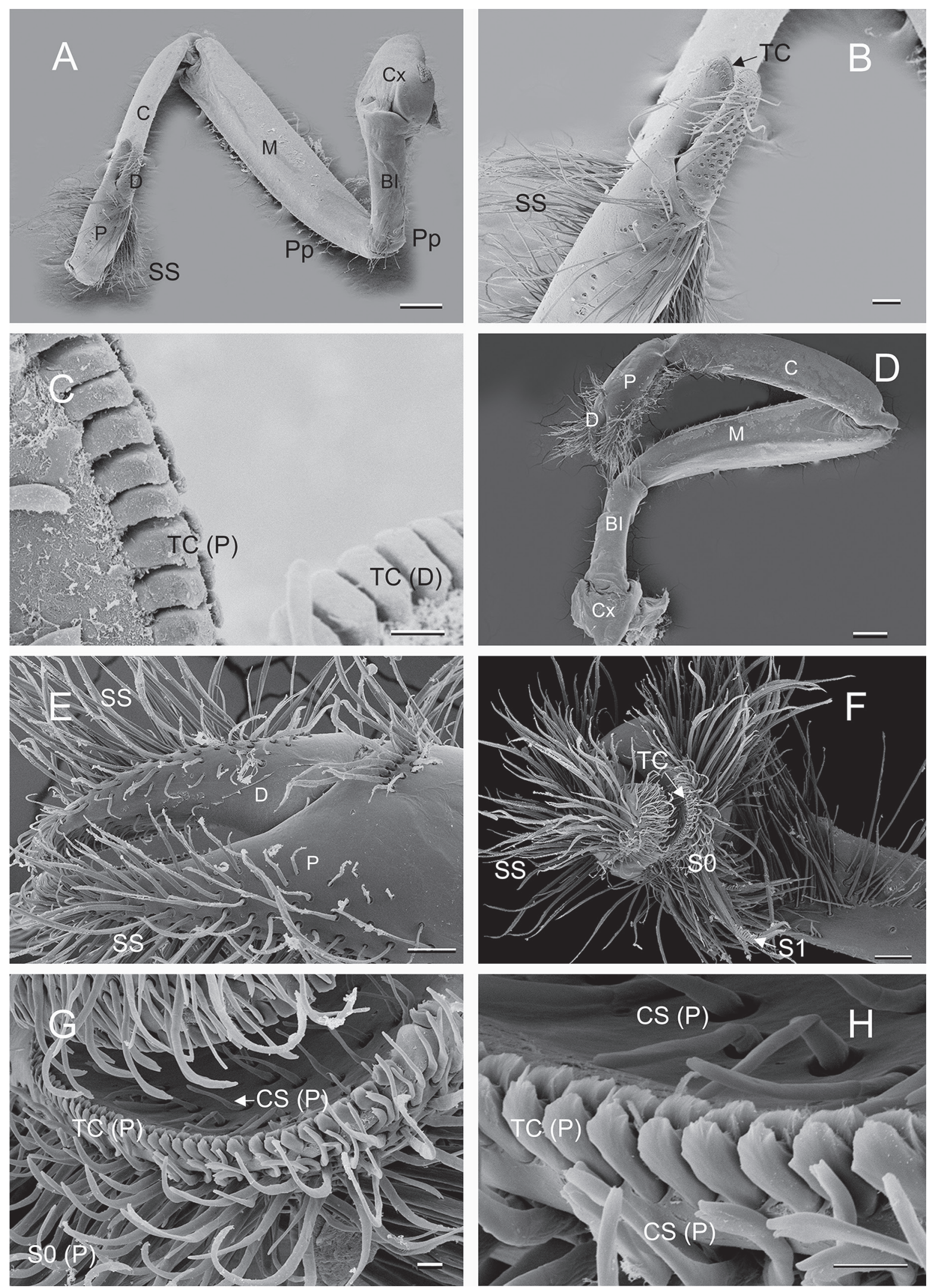

Figure 7. (A-C) Photomicrograph (SEM) of grooming leg, Porcellana platycheles (Pennant, 1777), male (MZUSP 16261). (A) Left P5, lateral view. (B) Dactylus and distal half of propodus, lateral view. (C) Tooth-like cuspidate setae on distal margin of dactylus and propodus. (D-H) Photomicrograph (SEM) of grooming leg, Porcellana sayana (Leach, 1820), male (MZUSP 28138). (D) Left P5, ventral view. (E) Dactylus and distal third of propodus, lateral view. (F) Distal surface of propodus and dactylus, frontal view. (G) Distal margin of propodus and dactylus, frontal view, with tooth-like cuspidate, club-shaped and simple setae. (H) Detail of tooth-like cuspidate setae and club-shaped setae on distal margin of propodus. Note in $\mathrm{E}$ distinct gap between fixed and movable fingers when chela is closed, and in $\mathrm{H}$ the tooth-like cuspidate setae provided with minute, unevenly sized, slightly acuminate teeth. $C x=$ coxa; $B \mathrm{I}=$ basis-ischium; $\mathrm{M}=$ merus; $\mathrm{C}=$ carpus; $\mathrm{P}=$ propodus; $\mathrm{D}=$ dactylus; $\mathrm{CS}=$ club-shaped setae; $\mathrm{Pp}=$ pappose setae; $\mathrm{SO}=$ simple setae; $\mathrm{S} 1$ = sickle-shaped serrate setae; $\mathrm{SS}=$ straight serrate setae; $\mathrm{TC}=$ tooth-like cuspidate setae. Scale bars $=(A, D) 0.3 \mathrm{~mm} ;(B, E, F) 0.1 \mathrm{~mm} ;(C, G, H) 0.01 \mathrm{~mm}$. 

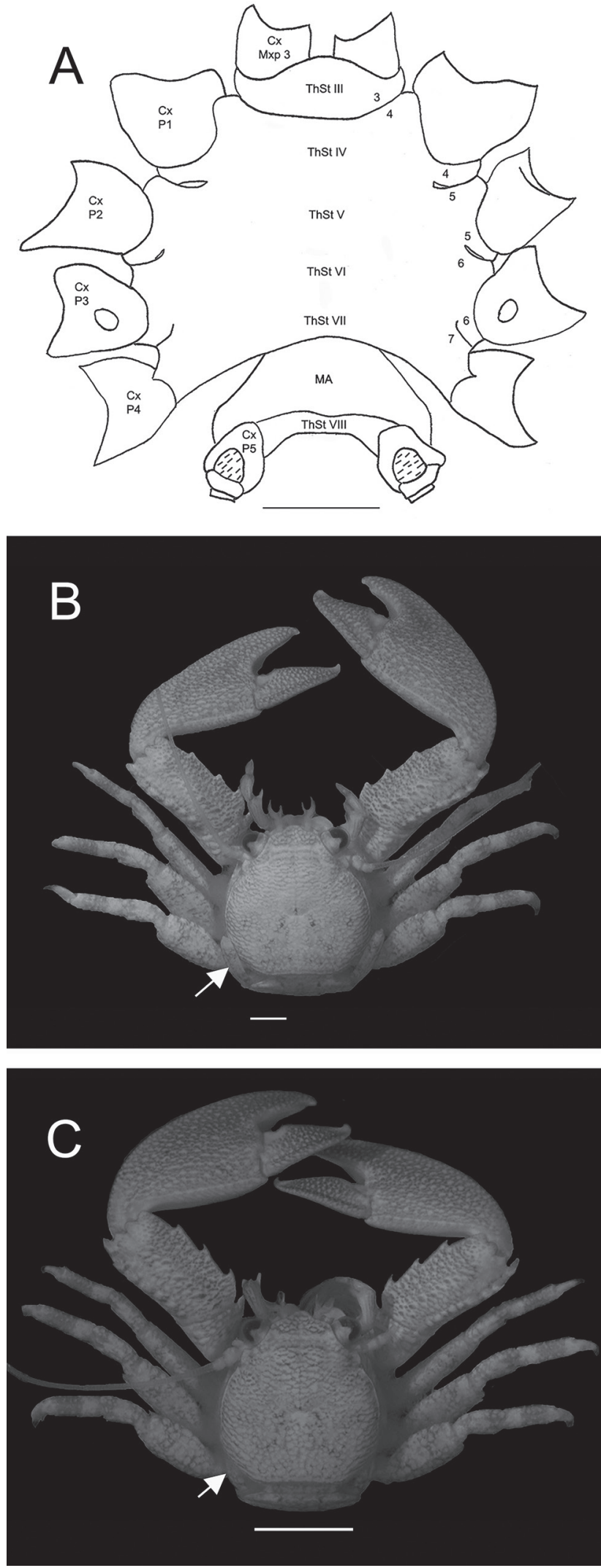

Figure 8. (A) Megalobrachium roseum (Rathbun, 1900). Schematic representation of the thoracic sternum in ventral view. $(B, C)$ Petrolisthes armatus (Gibbes, 1850), male, dorsal view (MZUSP 18688). (B) Grooming leg (arrow) folded in Z-form in resting position outside the branchial chamber. (C) Grooming leg (arrow) kept inside the branchial chamber. Abbreviations: CxP1-P5, coxae of pereiopods 1 to 5; CxMxp3, coxae of maxiliped 3; ThSt III-VIII, thoracic sternites III to VIII; $3 / 4-6 / 7$, thoracic sternal sutures; MA, membranous area. Scale bar: $(A)=1 \mathrm{~mm} .(B, C)=5 \mathrm{~mm}$.

\section{REFERENCES}

Bauer, R.T. 1977. Antifouling adaptations of marine shrimp (Crustacea: Decapoda: (aridea): functional morphology and adaptive significance of antennular preening by the third maxillipeds. Marine Biology, 40: 261-276.

Bauer, R.T. 1981. Grooming behavior and morphology in the decapod Crustacea. Journal of Crustacean Biology, 1(2): 153-173.

Bauer, R.T. 1989. Decapod crustacean grooming: Functional morphology, adaptative value, and phylogenetic significance. In: Felgenhauer, B.E.; Watling, L. \& Thistle, A.B. (Eds.). Functional morphology of feeding and grooming in Crustacea. Rotterdam, A.A. Balkema. p. 49-73. (Crustacean Issues, vol. 6)

Felgenhauer, B.E. 1987. Techniques for preparing crustaceans for Scanning Electron Microscopy. Journal of Crustacean Biology, 7(1): 71-76.

Fleischer, J.; Grell, M.; Høeg, J.T. \& Olesen, J. 1992. Morphology of grooming limbs in species of Petrolisthes and Pachycheles (Crustacea: Decapoda: Anomura: Porcellanidae): a scanning electron microscopy study. Marine Biology, 113: 425-435.

Forster, C. \& Baeza, J.A. 2001. Active brood care in the anomuran crab Petrolisthes violaceus (Decapoda: Anomura: Porcellanidae): grooming and brooded embryos by the fifth pereiopods. Journal of Crustacean Biology, 21(3): 606-615.

Garm, A. 2004a. Mechanical functions of setae from the mouth apparatus of seven species of decapod crustaceans. Journal of Morphology, 260: $85-100$.

Garm, A. 2004b. Revising the definition of the crustacean seta and setal classification systems based on examinations of the mouthpart setae of seven species of decapods. Zoological Journal of the Linnean Society, 142: 233-252.

Guinot, D.; Tavares, M. \& Castro, P. 2013. Significance of the sexual openings and supplementary structures on the phylogeny of the brachyuran crabs (Crustacea, Decapoda, Brachyura), with new nomina for higher-ranked podotreme taxa. Zootaxa Monograph, 3665(1): 1-414.

Høeg, J.T. 1985. Cypris settlement, kentrogon formation and host invasion in the parasitic barnacle Lernaeodiscus porcellanae (Müller) (Crustacea: Cirripedia: Rhizocephala). Acta Zoologica, 66: 1-45.

Holmquist, J.G. 1989. Grooming structure and function in some terrestrial Crustacea. In: Felgenhauer, B.E.; Watling, L. \& Thistle, A.B. (Eds.). Functional morphology of feeding and grooming in (rustacea. Rotterdam, A.A. Balkema. p. 95-114. (Crustacean Issues, vol. 6)

Keiler, J. \& Richter, S. 2011. Morphological diversity of setae on the grooming legs in Anomala (Decapoda: Reptantia) revealed by scanning electron microscopy. Zoologischer Anzeiger, 250: 343-366.

Martin, J.W. \& Abele, L.G. 1988. External morphology of the genus Aegla (Crustacea: Anomura: Aeglidae). Smithsonian Contributions to Zoology, 453: 1-46.

Pohle, G. 1989. Gill and embryo grooming in lithodid crabs: comparative functional based on Lithodes maja. In: Felgenhauer, B.E.; Watling, L. \& Thistle, A.B. (Eds.). Functional morphology of feeding and grooming in Crustacea. Rotterdam, A.A. Balkema. p. 75-94.

Ritchie, L.E. \& Høeg, J.T. 1981. The life history of Lernaeodiscus porcellanae (Crustacea, Rhizocephala) and co-evolution with its porcellanid host. Journal of Crustacean Biology, 1: 334-347.

Schembri, P.J. 1982. Functional-morphology of the mouthparts and associated structures of Pagurus rubricatus (Crustacea: Decapoda: Anomura) with special reference to feeding and grooming. Zoomorphology, 101: 17-38.

Watling, L. 1989. A classification system for crustacean setae based on the homology concept. In: Felgenhauer, B.E.; Watling, L. \& Thistle, A.B. (Eds.). Functional morphology of feeding and grooming in Crustacea. Rotterdam, A.A. Balkema. p. 15-26. 


\section{APPENDIX 1}

\section{Porcelain crabs studied in the present study. Collection numbers are indicated in parentheses.}

Megalobrachium pacificum Gore \& Abele, 1974; Panama, Puerto Armuelles, Río Mar, A. Anker \& J.F. Lazarus-Agudelo coll., 23 March 2015, 1 male (MZUSP 33141); Colombia, Los Negritos, St. 16, 0353'47.6"N, 77²4'09.3"W, A. Anker coll., 27 April 2009, intertidal, on coarse sand and sponges, 1 m, 1 female (MZUSP 33040); 1 male (MZUSP 33041).

Megalobrachium roseum (Rathbun, 1900); Panama, Portobelo Road, next to Mechi, A. Anker \& J.F. Lazarus-Agudelo coll., 25 March 2015, rocky intertidal, 1 female (MZUSP 33143); Brazil, Rio Grande do Norte, Praia de Cibaúna, F.J. Meira \& M. Christoffersen coll., 2 males, 1 female (MZUSP 7262).

Pachycheles grossimanus (Guérin, 1835); Chile, Atacama, Puerto Viejo, 27²0'04"S, 7056'28"W, G. Guzmán coll., 30 June 2012, associated with Lessonia sp, 2 male, 3 females (MZUSP 26392).

Petrolisthes armatus (Gibbes, 1850); Brazil, Bahia, Porto Seguro, Ponta Grande, St. 27, 16²2,641'S, 3900,342'W, M. Tavares et al. coll., 16 November 2010, intertidal, 0.6 m, 1 male (MZUSP 24562); São Paulo, Guarujá, Perequê, R.T. Bento \& P. Dall'Occo coll., March 2008, 2 males, 2 females (MZUSP 18688).

Petrolisthes tuberculatus (Guérin, 1835); Chile, Quintero, Cueva del Pirata, 3246'01"S, 71³1'59"W, N. Olguín \& G. Guzmán coll., 23 July 2012, 2 males, 2 females (MZUSP 25888).

Pisidia brasiliensis Haig in Rodrigues da Costa, 1968; Brazil, Santa Catarina, Penha, Itapocoroy, 2647'6.57"S, 48³6'46.24"W, E. Thomsen coll., 28 May 2010, 3 males, 3 females (MZUSP 23355).

Pisidia longicornis (Linnaeus, 1767); France, Granville, R. Buruko, Baba, A. Crosnier, R. Manning \& M. Tavares coll., August 1996, 2 males, 2 females (MZUSP 18730).

Polyonyx gibbesi Haig, 1956; Brazil, São Paulo, Ubatuba, 1 male, 1 female (MZUSP 19524); 3 males, 2 females (MZUSP 7149$).$

Porcellana platycheles (Pennant, 1777); France, Roscoff, June 2004, 3 males, 2 females (MZUSP 16261).

Porcellana sayana (Leach, 1820); Brazil, Rio de Janeiro, Niterói, Piratininga, 2307'55.64"S, 4302'04.06"W, J.B. Mendonça coll., 04 December 2012, 30-50 m, 2 males, 2 females (MZUSP 28138). 